\title{
THE GROWING IDPS IN THE COUNTRY AND IMPACT ON CHILDHOOD MALNUTRITION: AVERTING A FUTURE GENERATION WITH STUNTED GROWTH AND KNOWLEDGE
}

Jombo G.T.A ${ }^{I^{*}}$, Dabit O.J. ${ }^{2}$

Department of Medical Microbiology and Parasitology ${ }^{1}$ and Department of Paediatrics ${ }^{2}$, College of Health Sciences, Benue State University, Makurdi Nigeria.

*Corresponding Author: Jombo G.T.A, Professor of Clinical Microbiology and Parasitology, College of Health Sciences, Benue State University, PMB 102119, Makurdi, Nigeria

\begin{abstract}
$\mathrm{Al}$ least 80,000 people are forcefully displaced from their homes every 24 hour across the globe while in Nigeria the total number of IDPs in 2018 stands at 2.1 million. Among the major challenges facing the IDPs in camps scattered across the country is severe childhood malnutrition. This could lead to poor physical, mental and psychological development of children leading to the breeding of a large segment of children with stunted growth and associated compromised number recall, conceptual thinking, general cognition, and attention deficit which could manifest prominently in adult life. All efforts should therefore be intensified to meet adequate nutritional needs of all children in IDPs camps to ensure a healthy physical and mental future generation.
\end{abstract}

Keywords: Internally Displaced Persons, Malnutrition, Stunted Growth

\section{Introduction}

It is generally estimated that of the 7.6 billion people in the world as of January 2018, about 30.6 million of them are forcefully displaced from their homes and are either living in IDP camps, co-habiting with relations, friends or well wishers; or, are being taken care of by public spirited individuals or organizations in designated camps. This translates to a staggering 80,000 people being displaced every 24 hours. Others have sought asylum in distant lands and countries. Several factors have contributed to this growing trend ranging from communal, political and religious conflicts, wars, famine, insurgents and terrorism among others. ${ }^{1-4}$

In Nigeria not less than 2.1 million people at present are said to be internally displaced with the six northeastern states of Borno, Yobe, Adamawa, Taraba, Gombe and Bauchi alone accounting for over 1.7 million internally displaced persons (IDPs). Kaduna, Benue, Zamfara and FCT and other states with fewer IDPs constitute the remaining 1 million persons. The population of IDPs alone is more than the combined population of Ten countries of the world- Monaco, Palau, Bermuda, Tuvalu, Vatican,
San Marino, Iceland, Greenland, Cape Verde and Sao Tome and Principe put together. ${ }^{3-7}$

In Benue state alone it is estimated that there are not fewer than 80,000 children in the eight IDP camps are at the risk of facing severe malnutrition in the state due mainly to inadequate or non-availability of food. Similar reports have emanated among children from other IDP camps scattered across the country. Displaced children in homes of relations, friends and well wishers may severally be facing similar acute and protracted food shortages provided by their care givers.

The consequences of this include an increase in the proportion of children with stunted growth and other impaired physical development as well as impaired mental development among the myriads of complications of severe malnutrition. Malnourished children generally suffer Number Recall, impaired Conceptual Thinking, impaired general cognition, and attention deficit which if not corrected in childhood may progress into adult life. ${ }^{5,6,9,12}$

It is an established fact that these are the children that will grow into adulthood in the near future and occupy various segments of our society in academics, 
medicine, law, agriculture, engineering, science and technology among others. Denying them adequate and balanced nutrition would amount to setting a stage for a future generation of people with not just stunted height but ideas which are needed to administer various spheres of our affairs. ${ }^{13-17}$

No effort should be spared therefore by all to ensure that all children in IDP camps in the country are adequately well nourished so as to preserve the physical, mental and intellectual strength of the future.

\section{References}

1. National Population Commission (NPC). Number of IDPs in Nigeria up by $4.5 \%$ in January 2018. Sahara Reporters, New York, Apr 2018.

2. Webb P, Stordalen GA, Singh S, et al. Hunger and malnutrition in the $21^{\text {st }}$ century. BMJ 2018; 361: K2238.

3. Internal Displacement Monitoring Centre (IDMC). The number of internally displaced persons (IDPs) in Nigeria is growing quickly. IDMC Report Apr 2015.

4. Internal Displacement Monitoring Centre (IDMC). 2018 Global Report on Internal Displacement (GRID 2018). https://reliefweb.int/report/world/2018-globalreport-internal-displacement-grid-2018.

5. Displacement Tracking Matrix: Round XXI Report-February 2018, Nigeria.

6. Duru P. Farmers/Herdsmen crisis: 80,450 children trapped in eight IDP camps across Benue. Vanguard News, March 24, 2018, Nigeria.

7. Duru P. Malnutrition ravages 23,000 children in Benue IDPs camps. Vanguard News Apr 20 2018, Nigeria.

8. Akinsola HA, Ezeruigbo C, Kyei KA, et al. Sociodemographic determinants of body mass index among school children in Ebonyi state, Nigeria. Afr J Prim Health Care Fam Med 2018; 10(1): e1450.

9. Sanou AS, Diallo AH, Holding $\mathrm{P}$, et al. Association between stunting and neuropsychological outcomes among children in Burkina Faso, West Africa. Child Adolesc Psychiatry Ment Health. 2018; 12: e30.

10. Black RE, Victora CG, Walker SP, et al. Maternal and Child Nutrition Study Group Maternal and child under nutrition and overweight in lowincome and middle-income countries. Lancet
2013;382:427-51.10.1016/S0140-6736(13)60937$\mathrm{X}$

11. Jaacks LM, Slining MM, Popkin BM. Recent underweight and overweight trends by rural-urban residence among women in low- and middleincome countries. J Nutr 2015;145:352-7. 10.3945/jn.114.203562.

12. Hoddinot J, Rosegrant M, Torero M. 2012. Investments to reduce hunger and undernutrition. Copenhagen Consensus 2012 challenge paper: hunger and malnutrition. http://www.copenhagenconsensus.com/sites/defau lt/files/hungerandmalnutrition.pdf

13. Beal T, Massiot E, Arsenault JE, Smith MR, Hijmans RJ. Global trends in dietary micronutrient supplies and estimated prevalence of inadequate intakes. PLoS One 2017;12:e0175554.

14. McKay CM, Bell-Ellison BA, Wallace K, Ferron JM. A multilevel study of the associations between economic and social context, stage of adolescence, and physical activity and body mass index. Pediatrics. 2007;119(1):S84-S91.

15. Greve JM, Gug M, Dulgeroglu D, Brech GC, Castilho A. Relationship between anthropometric factors, gender and balance under unstable conditions in young adults. Biomed Res Int. 2013;2013:e850424.

16. Bangirana P, John CC, Idro R, Opoka RO, Byarugaba J, Jurek AM, et al. Socioeconomic predictors of cognition in Ugandan children: implications for community interventions. PLoS ONE.2009;4:e7898.doi:10.1371/journal.pone.000 7898.

17. Perignon M, Fiorentino M, Kuong K, Burja K, Parker M, Sisokhom S, et al. Stunting, poor iron status and parasite infection are significant risk factors for lower cognitive performance in Cambodian school-aged children. PLoS ONE. 2014;9:e112605. 